\title{
Stem cell transplantation in India: tall claims, questionable ethics
}

\author{
SUNIL K PANDYA
}

Department of neurosurgery, Jaslok Hospital and Research Centre, Mumbai 400026 INDIA email: shunil3@gmail.com

Understandably, medical professionals and patients, the world over, are agog to see the effects of stem cell transplantation in the treatment of diseases where current remedies have failed.

In countries where effective regulation ensures that medical practices remain ethical and scientific, the use of stem cells in the treatment of diseases such as those of the heart, liver, brain and spinal cord has remained in the experimental stage. Trials in animals have shown unexpected complications - such as the formation of tumours by the transplanted stem cells - in some cases. Very carefully controlled clinical trials in humans have been permitted in a few instances. The results are being closely monitored by experts not involved in the trials as well as those conducting them.

The National Institutes of Health, USA, notes, on its website: "Adult stem cells, such as blood-forming stem cells in bone marrow ... are currently the only type of stem cell commonly used to treat human diseases. Doctors have been transferring [such cells] in bone marrow transplants for over 40 years... The clinical potential of adult stem cells has also been demonstrated in the treatment of other human diseases that include diabetes and advanced kidney cancer. However, these newer uses have involved studies with a very limited number of patients." [Emphasis added]. (1)

In India we see a marked contrast. Individuals and institutions offer stem cell therapy to all patients. Claims are made on successful use of stem cells in curing diseases of the heart, liver and other organs; spinal cords damaged by injury and even cancer.

Take the following example reproduced verbatim from the website of Life Line Hospital in Chennai:

\section{"Spinal Cord Damage}

"Stem cells have found use in Patients with Muscular or Bladder paralysis after Spinal Cord Injury. In patients with paraplegia. This therapy is of maximum use in patients 1-2 years after Spinal cord injury. It could also be potentially of use for patients with other neurological diseases of the spinal cord. In the future the therapy may be useful for patients with Brain Damage also. Stem cell Injected directly into the Spinal fluid or around the spinal cord, at the site of injury has been found to improve nerve function. The Injection procedure is done under local anesthesia and is painless." (2)
The following section at this website is equally dramatic:

\section{“Cancer}

"Natural Killer cells (NK cells) which can be purified from the peripheral blood is found to be beneficial even in late cases of cancers like - Melanoma, Liver, pancreatic, lung and Gastric cancers."

I requested Life Line Hospital to send me references to publications in indexed journals on these and other uses of stem cells by their doctors, describing their experimental studies, clinical trials and actual use in patients. I have received no response. The website also claims: "All Stemcell (sic) trials in Life Line Hospital are registered with $\mathrm{NIH}$, USA and ICMR, India."

Dr Vasantha Muthuswamy, senior deputy director-general at the Indian Council for Medical Research (ICMR), informed me in a personal communication: "We have not given any approval to Lifeline Hospital." She elaborated: "ICMR has not given recognition to any centre for clinical applications. The only centres which we have cleared for basic research on stem cell biology [are] Manipal Acunova at Bangalore and Niche in stem cell research and regenerative medicine at Chennai." [Emphasis added]. I understand that Life Line Hospital obtains its stem cells from Niche. If this be so, both Life Line and Niche are guilty of unethical practices.

Here is another example:

"November 16, 2005: In the midst of controversy over the use of embryonic stem cells therapy for treatment, a private clinic on Wednesday claimed to have improved medical condition of 100 patients suffering from Alzheimer, paralysis and Parkinson's disease using the technique but government was cautious saying it would set up more operational guidelines for the area.

"The claim by $\mathrm{Nu}$ tech Mediworld, a registered in vitro Fertilisation and Genetic Centre in Delhi, was made in the presence of Union Health Secretary P K Hota." (3)

The clinic is headed by Dr Geeta Shroff.

On January 23, 2006, The Hindu reported a follow-up story from New Delhi: "The Government has ordered an inquiry into the activities of [this] clinic conducting embryonic stem cell therapy and warned of stringent action against those found violating the rules and guilty of playing with the health of unsuspecting patients, Health Minister Anbumani Ramadoss said. 
"We are conducting an inquiry into the claims of the clinic. Once the inquiry report comes, action will be taken against those responsible for violating the ethical norms and other issues,' Dr Anbumani said." (4)

My attempts at obtaining the findings of the inquiry and follow up action have failed. To the best of my knowledge, Dr Shroff sent scanty details on patients treated to the ICMR and did not turn up at a meeting of experts on spinal cord injury organised by it.

In August 2007, Paraplegia News reported: "Shroff has treated about 70 persons (including Mr Ajit Jogi, Chief Minister of Chattisgarh) for SCI (spinal cord injury). Although she believes that treatment would be optimal when started close to injury, most of her patients have been injured for at least a year. Basically, she decided not to treat the more acutely injured patients because critics would dismiss improvements as something that would have occurred anyway during a period in which functional gain is not uncommon." (5) It is noteworthy that all the treated paraplegic patients shown in this report, including Mr Jogi, are on chairs. None of them is shown standing or walking.

Worse, All India Institute of Medical Sciences (AlIMS), New Delhi, distributed information through the newspapers on success in treating cardiac disease in humans by using stem cell transplants. Attempts at obtaining information on the scientific basis for this therapy have not met with success. A search has failed to turn up publications on experimental studies, animal trials and phase 1 and 2 clinical trials in indexed medical journals trials prior to the newspaper reports. Since the proceedings of the ethics committee of this institution are unavailable to outsiders, we cannot learn of the discussions that preceded the clinical use of stem cells and the evidence of animal and other studies, if any, presented to the committee. Strangely enough, the director-general, ICMR, was quoted thus by The Hindu on April 5, 2005: "Dr N K Ganguly today said he stood by the authenticity of the work by the Institute (AIIMS)." (6) The basis for Dr Ganguly's certification is not available.

Dr Vasantha Muthuswamy, senior deputy director-general, has, however, courageously gone on record to state, with reference to these claims: "We are only a block away from AlIMS and we did not know this was happening there. If the nation's premier medical institute did not ask our permission for such therapy, how can we blame private clinics for what they do?" (7) She is understandably frustrated and voiced her feelings to the journal Nature, referring to the mushrooming of clinics offering stem cell therapy without any evidence that they were following basic ethical guidelines and scientific practice: "We want to promote stem-cell technology but not in this scandalous way." (8)

I was fortunate in being able to attend the session on stem cell therapy at the Second National Conference on Bioethics in Bangalore on December 8, 2007. The expert on the panel, Dr Bernard Lo, is professor of medicine and director of the programme on medical ethics at the University of California at San Francisco. He emphasised that whilst we have learned a lot on stem cells and their potential in medical practice, our knowledge on them is incomplete. He felt that we were not ready for the use of stem cells to cure disease or injury. He emphasised that unbridled usage could lead to complications (such as the formation of tumours) and bring stem cell therapy into disrepute. A member of the audience asked an important question. Pointing out that severe spinal cord injury causing paraplegia or quadriplegia was followed by a host of complications such as the formation of pressure ulcers, infections in the urinary system and lungs and an early death, he asked if it was wrong to use stem cells despite the current reservations. Dr Lo's reply was simple and to the point. He sympathised with the plight of the patient and the patient's family. He continued to have reservations on the clinical use of stem cells in spinal cord injury till we have more information. If, however, society in India felt that the use of stem cells in spinal cord injury was justified right away, the path to follow had to remain ethical and scientific. The carefully standardised treatment must remain confined to a few, carefully selected, major research hospitals and be strictly controlled and monitored. All the criteria used to process any clinical trial must be followed, detailed records maintained and the findings open to scrutiny. The patients and families must understand that the treatment is experimental and that unexpected complications may arise and jeopardise the well-being and even the lives of the patients. The patients must be followed up over a long period and findings - positive and negative - published in indexed medical journals.

Dr P M Bhargava, founding director of the Centre for Cellular and Molecular Biology, Hyderabad, was in the audience. His opinion was requested. He confirmed that stem cells were being used without authorisation or supervision in parts of the country and bemoaned the lack of a statutory agency that could act to prevent such usage.

His distress stems partly from statements such as that made by Health Secretary Prasanna Hota. He was the chief guest at a news conference held by fertility specialist Dr Geeta Shroff, who claimed in 2005 that she had treated over 100 patients with stem cell therapy. Hota said his presence should not be construed as an endorsement of the work but went on to say, "Sometimes, scientific knowledge cannot wait for bureaucratic apparatus." (9)

What is one to expect of institutions such as the ICMR where the director-general states: "We have no plan to legislate the guidelines that are in place for carrying out stem cell research... We will leave it to the medical profession to maintain a strict code of ethics." (6) Even on Christmas Day, 2007, the ICMR draft guidelines on the use of stem cells, cleared by the law ministry, await cabinet approval.

Why is it important that the guidelines be made mandatory by legislation? Failure of legislation permits blatant unethical practices. Consider the statement by Dorairajan Balasubramanian, research director at the LV Prasad Eye Institute in Hyderabad, himself involved in the use of stem 
cell to treat eye diseases. "Guidelines are only guidelines. Any violations cannot be punished." (9)

We are only too painfully aware of the fact that Dr Dhani Ram Baruah suffered nothing more than temporary inconvenience for his inhuman, unscientific and unethical act of transplanting the heart of a pig into a poor Assamese tribal with fatal consequences. In a manner later imitated by the AlIMS, Dr Baruah had claimed in the public media that medical science had taken a great leap forward with his operation. He too had no publications in indexed journals documenting his experimental and preclinical work (10).

Current practices suggest that we have a long way to go ere we can even approach the standards of scientific and ethical excellence that are the norm in many other countries. Our regulatory agencies are unwilling to act effectively when individuals or institutions flout required standards, especially when these are politically powerful.

If further proof of the ineptitude of our regulatory agencies is required we need look no further that the recent news items in our national dailies. Here is one such example pertaining to the trial in India of a vaccine against AIDS. This trial had been flagged off by Union Health Minister Anbumani Ramadoss and Union Science and Technology Minister Kapil Sibal at Pune's National AIDS Research Institute (NARI) and was a tripartite venture of the Indian Council of Medical Research (ICMR), the International AIDS Vaccine Initiative (IAVI), and the National AIDS Control Organization (NACO):

“On February 22, 2005 - 14 days into the trial in India - Targeted Genetics issued an official note on its European trial saying that 'the vaccine [AAV - tgAAC09] at the doses evaluated in this initial study did not elicit significant immune responses.....The vaccine had failed in Europe even though it had been tested on 50 individuals in a Phase-I trial meant to evaluate safety.

"Ironically, to accommodate the trial, India departed from its established regulatory procedure. Until this genetically engineered AIDS vaccine was tested in 2005, the policy was that ... a molecule or a vaccine developed in a foreign country could never be tested in India for a Phase-I trial until the host country where the molecule was invented had undertaken a full fledged Phase-Il trial.

"But this trial went ahead on the grounds that there was a health emergency and the need was to arrest the galloping epidemic of AIDS. Given the confidentiality clause of the trial, no independent verification has been possible on how the
Indian volunteers fared physically and/or psychologically in the Pune trial.

“Commenting on this, Dr P M Bhargava stated: 'There was no justification for the trial. It was unethical and totally uncalled for. The volunteers can't be treated like guinea pigs, they should have been told that the vaccine being tested on them had failed (elsewhere).'" (11)

ICMR, the department of biotechnology and the department of science and technology are just three of several governmental agencies, each independently approving and financing clinical research. Given the difficulty in monitoring such research and detecting unethical practices in this country, how are these agencies to ensure that norms are followed and deviations from it and proven unethical practices detected and penalised? Would it not make sense to ensure that a single agency approves, funds and monitors all clinical research in the country and empower it to penalise defaulters?

\section{References}

1. National Institutes of Health resource for stem cell research. Stem Cell Information. [Cited 2007 Dec 24 ]. Available from: http://stemcells.nih. gov/info/health.asp

2. www.stemcellindia.com. Spinal Cord Damage. [Cited 2007 Dec 24] Available from: http://www.stemcell-india.com/spinalcord-damage. htm

3. www.rediff.com. Clinic's embryonic stem cell therapy worries govt. 2005 Nov 16. [Cited 2007 Dec 24]. Available from: http://in.rediff.com/ news/2005/nov/16stem.htm

4. UNI. Government to act against clinic using stem cell therapy. The Hindu 2006 Jan 23. [Cited 2007 Dec 24]. Available from: http://www.hindu. com/2006/01/23/stories/2006012300720900.htm

5. Johnston L. Embryonic stem-cell therapy. [Cited 2007 Dec 24]. Available from: http://www.healingtherapies.info/hESC.htm\#Overview

6. Staff reporter. ICMR okays stem cell research by AlIMS. The Hindu 2005 Apr 5. [Cited 2007 Dec 24]. Available from: http://www.thehindu. com/2005/04/06/stories/2005040612771300.htm

7. Srinivasan S. Clinical Trials - part IV: Rogue research in the guise of stem cell therapy. Infochange features [Cited 2007 Dec 24]. Available from: http://www.infochangeindia.org/features326.jsp .

8. Jayaraman KS. Indian regulations fail to monitor growing stem-cell use in clinics. Nature 2005 Mar 17; 434 (259). [Cited 2007 Dec 24]. Available from:http://www.nature.com/nature/journal/v434/n7031/full/434259a. html

9. Mudur GS. Stem cell march, minus checks - Lack of research rules allows doctors to do as they like. The Telegraph 200516 Nov. [Cited 2007 Dec 24]. Available from: http://www.telegraphindia.com/1051117/asp/ nation/story_5487047.asp

10. Vox populi. The first Indian porcine transplant. Issues Med Ethics 1997 Apr-Jun; 5 (2). [Cited 2007 Dec 24]. Available from: http://www.ijme. in/052mi062.html

11. Bagla P. Despite note that AIDS vaccine had failed, India changed rules and continued trials. The Indian Express 2007 Dec. [Cited 2007 Dec 31]. Available from: 23 http://www.indianexpress.com/sunday/ story/253329.html 